\title{
The Flood
}

\section{Paulette Callen \\ New York, New York}

It began with a wind murmuring in an ancient and new

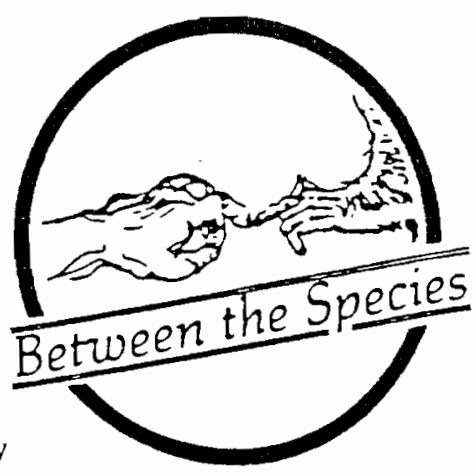

voice; the sea nations heard, and only

one man. He told his wife

who said, "Ah, you're drunk again." His sons

thought the same. Their wives said nothing

and listened. They, too, heard the voice

of the wind and gathering close their garments, grew quieter

still. They brought cool water to their father-in-law

as he, in obedience to the voice, hauled rough-

cut planks of cedar-hard labor

for a six-hundred-year-old man.

His sons watched their wives and then began to

listen and soon to hear and help their father.

The old man's wife never heard

the voice, but kept them fed and washed, clothes

clean and mended, and dreamed of being a grandmother.

Poised in twilight, she quivered from nose to tail, smelling, feeling, awash in the wind. He stepped out of the blackness of the trees, received her gaze; utterly still they fathomed each other and the wind. Delicate, carved, polished, black, adamantine hooves tamped ground, then gracile limbs powered by iron-sprung haunches and chests, deep and wide for drinking the wind, leapt together into the wind-tide, eastward, the stag and his mate.

The wind furroughed the backs of the pack lounging outside the den, digesting their kill and watching pups stalk and maul each other. It was not the alpha wolf who rose, shook himself, pricked his ears, and began to lope due east, moon rising in his eyes, but a young dog a year before his prime. The she-wolf running east converged and matched her strides with his. They covered ground their huge feet did not seem to touch, running swiftly, running for days on end, running without rest, without weariness, as if born on the wind itself. 
The Matriarch wept and flung her head

side to side, swaying and stamping in grief.

Her sister, close, caressed her, but she would not be soothed. A wind had swept over them at the watering place. The young one had lifted her trunk to test it, closed her eyes and seemed to go within.

The Matriarch watched, helpless to affect some terrible thing she knew was happening, as her daughter, favored child, stepped up out of the water, trotted into the wind and left the family. (The bull saw her coming, tiny by his measure, and his eyes filled with tears. He'd known many females who'd suffered his attention but this one, so young, would need his care.)

Among twigs

and leaves, across vines and loose stones, huge paws landed and broke nothing, disturbed nothing, made no sound: a step he could maintain at all but his top speed. He moved, shadow among shadows, knowing she was there, not by her scent, for she was not in season, nor by her cry, for she had made none. Gold with green gold eyes, she waited. He approached. A growl begat by instinct surged from his belly but he ignored it and she, before the wind, would have feared him, who now whirled and without caution began to run. He was a loner, but he would go with her. He had been chosen.

Thus the wind, the wind of doom, the reckoning wind, wind of the Lord's own sorrow, swept the earth, Destroyer and Preserver. For as it summoned the clouds and churned the waters it chose some to cipher its message. Antennae throbbed, whiskers maneuvered, tails twitched, and sticky red tongues snapped out to taste the wind. Guard hairs stood erect, muscles tightened and released in speed or lumbering strength, in stealth or ground-close scurrying, each according to his nature, each according to her kind. From dens and aeries, balmy plains and the murky depths of jungle and swamp; from blazoned snow-lands, dappled forest worlds and shadowless deserts, they came. Answering the wind. Each in his own way. Each in her own time. They came.

Noah stood at the threshold of the ark, chills shot up his spine in spite of the heat. His knees shook and his eyes streamed. (He was always maudlin 
in his cups, but he'd had nothing to drink for weeks.) He had built the ark in obedience, on faith, knowing for whom he was building it. For them. But seeing them-in their numbers, in their unbearable humility, in their strength and fragility-he wept.

to come had been the birds, alighting on the roof

The first of the ark. Many flew by but did not light. All the birds in the world could have landed on the ark, sinking it into the mud where it stood, but they did not-only the chosen, from little brown birds, so plain they disappeared against the rough wood, to birds of such bright plumage they took his breath, he had never seen such glory. Such ones existed in the world! He hadn't dreamed.

They came without fear two by two. The horizon flowed rivers of beings: multitudinous forms, shaggy and sleek, scaled and smooth.

They came hopping on twos, prancing on fours; feet padded, flippered, and clawed, webbed, and hooved, or slithered on none making good time still.

They came shells on their backs, pouches on their fronts, homs on their heads or protruding out their mouths; in colors of rainbows, and of old leaves. The clowns. The majestics.

They came, eyes like moons or setting suns, like mossy pools sunlit from below, like fire-lit ice or haunted brown of unknown depths.

They came with fingers and toes, grasping tails and old-man-like faces, scampering up the ramp like wizened children. Lizards of a size that could only have been spawned from his most drunken nightmare, steadfastly plodded up the gangplank. Tiny, many-eyed, many-legged creatures floated by him, or clung to the backs and heads and tails of larger folk possibly unfelt by them. (There he saw a spider with her mate-he fat and sleepy, looking forward to her spinning thein a silver traveling berth; she deigning not to eat him for the present.) They came, fantastic, 
beloved of God. All to be cared for.

This is my work. The old man trembled and wanted a drink.

For days and nights they came, and Noah's sons took turns holding him up as he greeted each one who entered the ark. Then came the last two: a small white dog and a small brown one. Noah didn't know which was the he and which the she, but it didn't matter. The clouds boiled white froth that congealed into a black tide that rolled from earth's edge to earth's edge. Light and color drowned in a sea of black. Lightning screeched through the heavens like pain; the Earth roared in anguish as she opened; her fountains gushed from the deep.

Then Noah

and his sons closed the ark, huddled in the lower deck, and listened to the wrath of God. The boat trembled and bravely stood the scathing wind wielding the sword of purgation-water: sustainer of all life, now become destroyer.

The ark shuddered as if to break apart as the ground was lost to water, and the old man prayed, Please let this thing float. It did.

Still he could not rest. He thought he heard the wailing of all mankind. He wept bitterly and covered his head and could not hear the singing and did not notice the silence of the animals both inside and outside the ark.

His daughters-in-law quietly

roamed the vessel stroking soft noses, scratching ears, filling troughs, mangers, and bowls. The small, hairy creatures with their old-manfaces, embraced them, played with their earrings, stole their bracelets, chattered and made them laugh. The two little dogs trotted after them, fearing no one, not even the old bull elephant (wisdom having its place in the ark along with fecundity) who was the resident giant, even beside the mammoth female (of whom he was greatly solicitous for she missed her mother), for he was good and always looked before he stepped. The birds of every kind, each with his own song, filled the decks with music. The cats lapped milk and purred and licked themselves all over until they gleamed in the torch-lit hold. The wolves and bears munched 
heavy cakes made with every kind of grain and oil and herb, licked each other and dozed in beds of straw. The cows, ewes, and she-goats mothered the voyagers with their milk, and chewed their grasses in the shadows of proud bulls and rams.

Creeping things spun themselves into pods and dangled from the rafters to emerge later in celebration.

After forty days and nights the wailing ceased, wind and rain withdrew; the singing subsided. The ark came to rest on still water. Noah uncovered his head. He opened a window and peered out. Everywhere was water and nothing nothing else. The wives of Shem, Ham, and Japheth climbed to the outside deck, breathed hungrily, loosed their hair and bared their skin to the sun. They scanned the watery world for the singers. What kind of beings must they be? Angels? They had, of course, to be angels. Would they show themselves? Then they saw a blackness shadowing still and strong from the depths of the sea. They heard a mighty rumble and swoosh! as the waters parted. Out of the sea before them rose leviathan-first of creation. She cleft the water-an impossible ascent from liquid to air, the only solid thing, herself, whirling and falling on her side in a seadisplacing splash. Her hieroglyphic flukes smacked the surface as she dived-in the distance, two more such ones of a size they could scarcely comprehend, never having seen mountains at play. The women felt no fear. As if to reassure them anyway, the little shepherds of the sea appeared, dancing around the boat. The women began to clap and dance. Their men joined in. Even Noah's wife peered in awe at the smiling behemoths and the small ones frolicking about their tiny ark in the great great vastmess of the spangled sea. The survivors of God's anger beheld the beings who flourished beneath the waves, and wondered, and felt at peace.

For the sea nations had not brought down the Lord's regret. They shown like shining lights in God's eyes. The small ones had asked, in pity for their earthbound brothers and sisters, that they might, with dolphin mind and agile corporeal forms, encompass and surround them to ease their passage. This 
the Lord allowed. The giants of the sea, too, felt compassion for the creatures of the land, for the terror that was theirs to come. What can we do? they prayed. We are so large, we will add to their terror if they see us coming at them through the waves. The little ones among them won't even be able to see us as we are. We will be to them like walls, like mountains, like dark moons. Give us a means to comfort them. The Lord heard their prayer and gifted them with song. And when the rains came they began to sing and filled the earth and skies and waters with their songs, and the animals stopped scrambling in fear and listened and were comforted and waited as the waters rose. The spheres resounded with song from the little blue planet for an awesome thing was happening there. And as the waters rose the shepherds camethe dolphins-leaping and laughing, beaming serenity to guide them in joy and peace; compassion filled the stormy seas as they surrounded each dying creature with love easing him or her into the next world. Be not afraid. Nothing dies, all is spirit. All is reborn. Be at peace.

But men fought each other for higher ground, lost their senses, wailing and cursing, so they could not hear the whales singing them hope and comfort, nor feel dolphin mind ready to guide them safely from the disappearing earth to the infinite realm of light and spirit. Drowned in the maelstrom of their own lamentations, mankind passed over into darkness in needless anguish and wandered till their rage was spent and their fear dissolved. It took a long time for them to find their way to the light.

The ark floated on. The whales sang now to comfort the survivors who sometimes howled in anguish over lost tribes, or trumpeted in grief for memories of wrinkled faces and loving eyes, or paced, restless for a territory to study and conquer. And Noah prayed his prayers morning and evening and fondled the seeds in his pocket that held the promise of new vines. His wife comforted him and kept a close eye on the bellies of her daughters-in-law. Ham, Shem, and Japhet kept the boat in repair. It would leak. 
And the young women loved and nurtured and were loved and nurtured by the creatures on the ark. The wind rose again, rocking the ark like a cradle. The sky stayed bright, the sun hot, and the waters receded.

The birds left first.

The sea of water turned to a sea of mud and still, all but the birds could not go far, but the wind sucked the mud dry, and the earth became firm and even green, and the rainbow came, sign of the covenant He had made, the Lord God, with the race of men and the species, every one, He had saved on the ark. And to the minds in the waters who had served the earth's creatures in their dying hours, the Lord God said, "You will save and shepherd mankind and sing for the peace of all living things. This is your covenant, first of my children. But you will pay dearly, for the riders of the ark have inherited corruption. You will have to sing them back again and again."

The singing hasn't stopped.

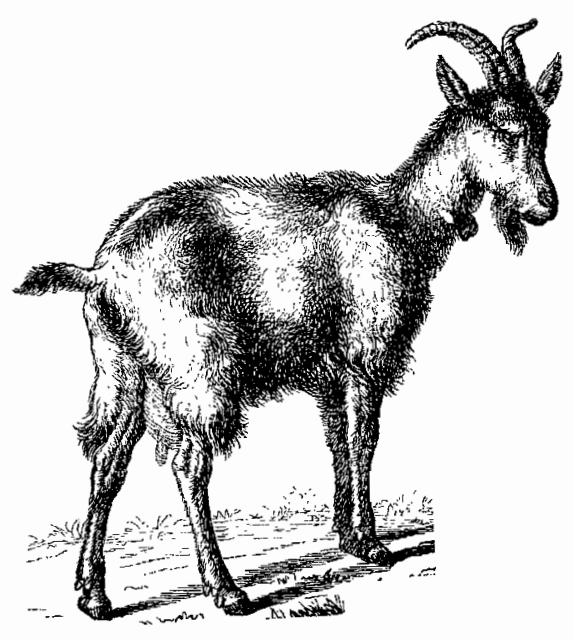

